\title{
NEWS FOR THE MEMBERS
}

\section{MIDDIE EAST FILM FESTIVAL}

The first Middle East Film Festival will be held June 4th11th at the Bleecker St. Cinema in New York's Greenwich Village. The Festival is being organized by independent filmmakers in cooperation with the Bleecker St. Cinema to provide a forum for artists and points of view that do not receive adequate exposure in the United States. Filmmakers from Egypt, Iran, Israe1, and Kuwait will be at the Festival to discuss their works. These filmmakers include: Laila Abou-Saif, an Egyptian director and actress whose film "I Want My Freedom" explores the history and impact of feminism in Egypt (Ms. Abou-Saif was a MESA Visiting Scholar in 1975); Igal Niddam, an Israeli filrnmaker whose film "We Are All Jewish Arabs" received the Critic's Award at the 1977 International Film Festival in Brussels; Marva Nabili, Iran's only woman director/producer, who wrote and directed "The sealed Soil;" and Khalid Seddick, a Kuwaiti filmmaker, whose film, "The Cruel sea," about pearl-diving in the Gulf, will be shown.

Each day of the Festival will feature separate afternoon and evening screenings organized around the following themes: Monday, June 4 th Women in the Middle East

Monday

Tuesday

Wednesday and

Thursday

Friday
Tradition in Transition

The Struggle for Social Change

Battle Scars: Arabs and Israelis

Films and Panel Discussions on: the Civil war in Iebanon; young Israeli cinema; and artistic freedom in the Middle East.

A complete schedule of films will be available May lst. Among the films to be shown are several that have had some U.S. exposure (e.g.. Susan Sontag's "Promised Lands," as well as several U.S. premieres.

The Festival will conclude with a day-long conference with the visiting filmmakers on Sunday, June 11th, at the Village Gate, on "The Role of the Media in the Middle East."

Tickets are being sold in advance and series tickets are $\$ 30.00$ for general admission and $\$ 20.00$ for students and senior citizens. These tickets are at a discount from the price of individual tickets sold at the door, and guarantee seating in what is a small theater. Tickets and further information are available from:

The Middle East Film Festival

The Bleecker st. Cinema

144 Bleecker st.

New York, New York 10012 
The American institute for Research in Yemen was established in the fall of 1977. The purpose of this interdisciplinary nonprofit organization is to encourage communication between American and Yemeni scholars and to facilitate scholarly research in the Arab Republic of Yemen. For further information write: The American Institute for Research in Yemen 5848 South University Avenue Chicago, Illinois 60637

PRIVATE PAPERS COLLECTION -- ST. ANTONY'S COLLEGE, OXFORD

The Middle East Centre at St. Antony's College, Oxford, has a collection of private papers that is available for scholarly use. The collection, started in 1961 by Elizabeth Monroe and Albert Hourani, is a rapidly expanding gathering of the papers, both personal and official, of individuals who served in the Middle East. Included are papers of British Government officials, business men, bankers, and travellers. Gifts of papers have been given the name of the donor, regardless of the content of the collection or the amount of material by the donor to be found in other peoples' collections. The cataloguing system provides both an author index and a subject index for information about a particular topic or country. Also in the catalogue are all available details of relevant Middle Eastern collections both inside and outside the U.K., held either by individuals or learned institutions; in other words, the catalogue serves as a union list of Middle Eastern private papers for the nineteenth and twentieth centuries. Inquiries should be addressed to:

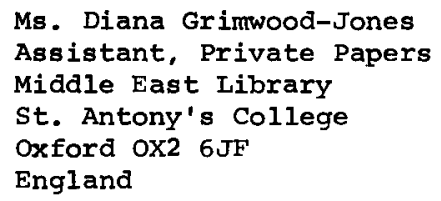

\section{PLACEMENT LISTINGS}

Our list of people available for employment has produced little response in recent years, so we have discontinued printing it in the Bulletin. We will, of course, retain all letters and curricula vitae in a file at the Secretariat, which will be available for consulation by prospective employers. Currently, we have several letters from foreign scholars seeking jobs in the United States.

\section{PLACEMENT OPPORTUNITIES}

CLARK UNIVERS ITY

Clark has three one-year assistant professorships open for September 1978: 